\title{
Gene Regulation of Biofilm-Associated Functional Amyloids
}

\author{
Khushal Khambhati, Jaykumar Patel, Vijaylaxmi Saxena, Parvathy A and Neha Jain *
}

Citation: Khambhati, K.; Patel, J.;

Saxena, V.; A, P.; Jain, N. Gene Regulation of Biofilm-Associated Functional Amyloids. Pathogens 2021, 10, 490. https://doi.org/10.3390/ pathogens10040490

Academic Editor: Jan-Ulrik Dahl

Received: 15 March 2021

Accepted: 15 April 2021

Published: 19 April 2021

Publisher's Note: MDPI stays neutral with regard to jurisdictional claims in published maps and institutional affiliations.

Copyright: (c) 2021 by the authors. Licensee MDPI, Basel, Switzerland. This article is an open access article distributed under the terms and conditions of the Creative Commons Attribution (CC BY) license (https:// creativecommons.org/licenses/by/ $4.0 /)$.
Department of Bioscience and Bioengineering, Indian Institute of Technology Jodhpur NH 65, Nagaur Road, Karwar, Rajasthan 342037, India; khambhati.1@iitj.ac.in (K.K.); patel.12@iitj.ac.in (J.P.); vijaylaxmis@iitj.ac.in (V.S.); parvathy.1@iitj.ac.in (P.A.)

* Correspondence: njain@iitj.ac.in

\begin{abstract}
Biofilms are bacterial communities encased in a rigid yet dynamic extracellular matrix. The sociobiology of bacterial communities within a biofilm is astonishing, with environmental factors playing a crucial role in determining the switch from planktonic to a sessile form of life. The mechanism of biofilm biogenesis is an intriguingly complex phenomenon governed by the tight regulation of expression of various biofilm-matrix components. One of the major constituents of the biofilm matrix is proteinaceous polymers called amyloids. Since the discovery, the significance of biofilm-associated amyloids in adhesion, aggregation, protection, and infection development has been much appreciated. The amyloid expression and assembly is regulated spatio-temporarily within the bacterial cells to perform a diverse function. This review provides a comprehensive account of the genetic regulation associated with the expression of amyloids in bacteria. The stringent control ensures optimal utilization of amyloid scaffold during biofilm biogenesis. We conclude the review by summarizing environmental factors influencing the expression and regulation of amyloids.
\end{abstract}

Keywords: biofilms; functional amyloids; gene regulation; extracellular matrix; CsgA; TasA; PSM

\section{Introduction}

Biofilm is an aggregative behavior of microbial cells for self-protection and better survival [1]. Microbes within a biofilm can cooperate and coordinate with each other allowing them to adopt a community-based lifestyle [2]. Initially, marine microbiologists used the term "biofilm" to distinguish planktonic and adherent bacterial cells, but sooner, it was recognized as a major concern for both environment and human health [3]. Bacterial colony within a biofilm is encapsulated by an extracellular matrix (ECM) that aids in substrate adhesion [2] and acts as a stronghold for microbial cells against environmental insults [1]. It facilitates water retention, absorption of inorganic ions and organic compounds, excess carbon storage, horizontal gene transfer, polymicrobial interaction, mechanical stability, antibiotic resistance, and biofilm architecture development [1,4-6]. Macromolecules, such as extracellular DNA (eDNA), polysaccharides, and proteins are the key components of the biofilm matrix [4]. The proteinaceous bacterial ECM components consist of pili, flagella, adhesins, secreted extracellular proteins, and proteins of outer membrane vesicles [7].

One of the secreted ECM proteinaceous components of a bacterial biofilm matrix is amyloids [8]. Amyloids are structured protein aggregates initially known to be associated exclusively with the pathological manifestation of human diseases [9]. However, the notion changed with the attribution of functional roles to the amyloids [10]. Both pathological and functional amyloids share similar biophysical and biochemical features [10-12]. Functional amyloids are ubiquitous and play a pivotal role in biofilm development, growth of aerial structures, modulation of melanin synthesis, scaffolding, epigenetic control of polyamines, and transmission of genetic information [12,13].

The amyloid scaffold is a well-suited structure for biofilm assembly since it provides rigidity and stiffness to the matrix [14]. Figure 1 summarizes the discovery of biofilm-associated amyloids in Escherichia coli (CsgA and CsgB; curli specific gene) [15], 
Pseudomonas aeruginosa (Fap) [16], Bacillus subtilis (TasA and TapA) [17], and Staphylococcus aureus (phenol soluble modulins: PSMs and biofilm-associated proteins: Bap) $[18,19]$. As a part of the biofilm matrix, amyloids contribute to adhesion onto the abiotic and biotic surface, increase hydrophobicity and promote colonization [20]. They also increase structural stability, provide resistance against environmental stresses, drive protection against phage particles and matrix-degrading enzymes [21]. Apart from functional roles, bacterial amyloids are also associated with disease pathology and are known to enhance gut inflammation, provoke host cytolysis, and influence neuronal-inflammation and cerebral amyloid aggregation [22,23]. Some of them are recognized as microbial-associated molecular patterns (MAMPs) and help evoke host immune response [24]. Overall, functional amyloids play a major role in biofilm formation and contribute to disease progression. Therefore, it is essential to understand the regulatory mechanism that controls amyloid assembly during biofilm development.

\section{9}

Curli - First identified as novel class of organelle present on E. coli surface

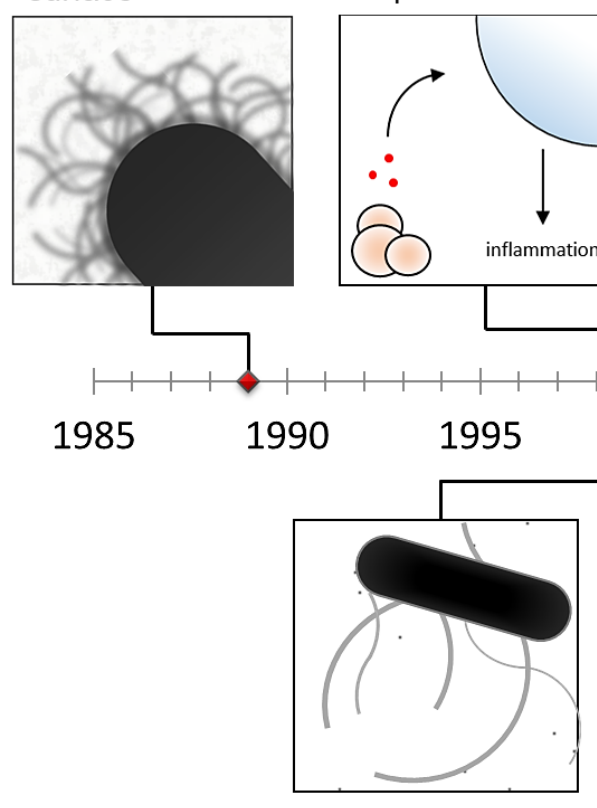

2010

Amyloidogenic nature of TasA was characterized

\section{9}

PSMs - First

identified in

S. epidermidis

provoking

inflammatory

response

\section{9}

TasA - First recognize as a Bacillus spore associated protein

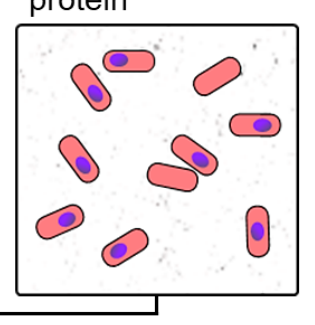

\section{1}

Bap - Discovered

as a protein

involved in

S. aureus biofilm formation

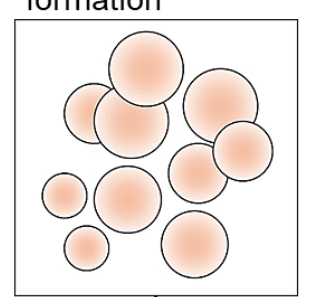

\section{2}

CsgA was

characterized as protein forming amyloids

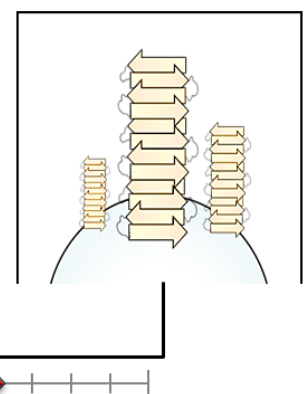

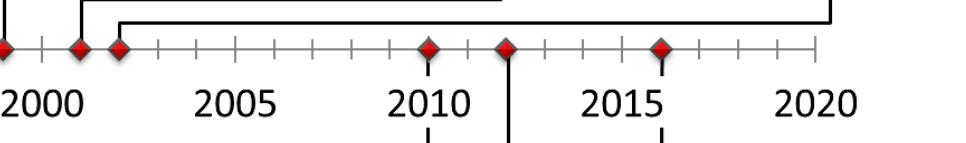

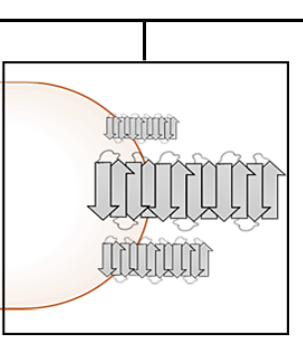

2010

Pseudomonas Fap was discovered and its amyloidogenic nature was characterized

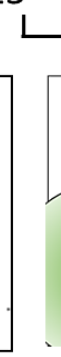

2012

PSMs were found to form amyloids

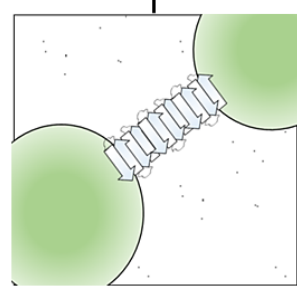

2016

Amyloidogenic nature of Bap was characterized

Figure 1. Timeline representing the discovery of functional amyloids.

In this review, we discussed the genetic regulation that controls the expression of functional amyloids in E. coli, B. subtilis, and S. aureus. As a prelude, we briefly described biofilm formation and its genetic regulation, followed by a detailed description of the gene regulation of amyloids associated with biofilm formation. The description of genetic regulation of all the matrix components of biofilm is beyond the scope of this review. Since the environment directly influences biofilm formation, we also described the environmental signals that regulate the expression of functional amyloids. Understanding the 
regulatory mechanism of functional amyloids may help tackle biofilm-related diseases in an improvised manner and provide new avenues for drug discovery.

\section{Biofilm Assembly and Its Gene Regulation}

Biofilms are highly heterogeneous bacterial communities, where the 3D architecture and chemical composition change according to environmental conditions [2,6]. Despite heterogeneity in composition and structure, biofilm assembly is a uniform process in most bacteria [6]. The stages involved in biofilm biogenesis can be briefly described as (1) reversible attachment to the surface, (2) irreversible and stable attachment, (3) proliferation and microcolony formation, (4) maturation, and (5) dispersion [1]. Mature biofilm provides bacteria several advantages over the planktonic lifestyle and remains as one of the most featured adaptations.

Biofilm formation is regulated by various intracellular and intercellular signaling systems [25]. The major signaling systems responsible for the synthesis and assembly of various matrix constituents during biofilm formation include quorum sensing, bis-( $\left.3^{\prime}-5^{\prime}\right)$ cyclic diguanosine monophosphate (c-di-GMP) signaling, and non-coding small RNAs (sRNA) [25]. Quorum sensing allows bacteria to detect cell density change through autoinducers and respond via a change in gene expression [26]. Modulation in intracellular levels of c-di-GMP leads to differential gene expression profile. Higher c-di-GMP concentration results in inhibition of motility, induce matrix-associated polysaccharide and adhesins synthesis [25]. sRNAs have been reported to regulate exopolysaccharide synthesis and export, amyloid expression, and motility [25].

\section{Gene Regulation of Bacterial Functional Amyloids during Biofilm Assembly}

\subsection{Escherichia}

E. coli express proteinaceous fibrils-like structures called curli, which are essential for cell contact and promote host colonization [15]. Curli elicit close interactions with surfaces and form inter-bacterial bundles permitting a stable cell association within the biofilm $[27,28]$. Chapman and his colleagues were the pioneers to provide a breakthrough in understanding the amyloid characteristics of proteins in bacteria by discovering curli in biofilms [15]. Curli is one of the best-studied bacterial functional amyloids [29]. The expression and translocation of curli are governed by curli specific genes (csg) encoded by $\operatorname{csg} B A C$ operon [30]. $\operatorname{csg} B A C$ encodes for minor curli subunit CsgB, major curli subunit CsgA, and periplasmic protein CsgC, respectively [30]. Under biofilm-forming conditions, curli assembly is initiated by CsgB that provides a suitable template for efficient CsgA amyloid assembly on the outer cell surface $[31,32]$. CsgC is a periplasmic protein that keeps CsgA in a soluble form within the cells [33]. Another operon csgDEFG encodes four accessory proteins that are essential for proper curli assembly [15]. CsgG is an outer membrane nonameric lipoprotein that aids in the secretion of CsgA and CsgB curli subunits [34]. CsgE alters CsgG pore properties and adds specificity to CsgG-dependent secretion [35,36]. Within the cells, CsgE also helps in maintaining CsgA in its soluble state $[35,36]$. CsgF is a curli adaptor protein that facilitates curli amyloid assembly onto the cell surface [37]. Curli biogenesis is a highly regulated process controlled by various genes and gene products [38]. The highly robust nature, striking mechanical properties, and stiffness like silk makes curli an exciting system to understand the machinery that modulates its expression [39]. Here we shed light on the significant regulators of curli expression:

CsgD: CsgD is a FixJ/LuxR transcriptional family master regulator protein that positively regulates csg expression [40]. The expression of CsgD is modulated at both transcriptional and post-transcriptional levels by regulatory proteins and sRNAs [41]. OmpR, RcdB, PlaR, H-NS, RstA, CpxR, and IHF are the major transcriptional factors that recognize the environmental cues and accordingly affect $\operatorname{csg} D$ expression [41]. OmpR, IH-F, RcdB, and Rst $\mathrm{A}$ are positive regulators, while PlaR, $\mathrm{CpxR}$, and $\mathrm{H}-\mathrm{NS}$ are negative regulators of $\operatorname{csg} D$ 
expression [41]. Besides these, the complex of catabolite repressor protein and cyclic AMP also influence curli expression by positively regulating $\operatorname{csg} D$ transcription [42].

sRNAs: sRNAs such as McaS, OmrA, OmrB, RprA, RydC, RybB, and GcvB downregulate $\operatorname{csg} D$ expression [43-45]. RydC is a trans encoded sRNA that makes a complex with host factor I protein (Hfq), which is paired with transcription initiation sequences (TIS) of $\operatorname{csg} D$ mRNA [44]. The stable complex between RydC-Hfq and $\operatorname{csg} D$ mRNA hampers $\operatorname{csg} D$ expression, reducing $\operatorname{csg} B A C$ transcription, thereby drastically impairing curli biogenesis and biofilm formation [44]. RydC-Hfq mediated $\operatorname{csg} D$ downregulation is suggested to be a potential mechanism for E. coli to switch between planktonic and sessile state [44]. On the contrary, McaS, RprA, and GcvB interact with Hfq and RNaseE, thereby inducing ribonucleolytic cleavage of $\operatorname{csg} D \mathrm{mRNA}$ and abolishing curli expression [45]. The OmrA/B set of sRNAs also drastically reduces $\operatorname{csg} D$ expression by inducing translational inhibition and abolishes curli synthesis [43].

Tol-Pal system: E. coli has a Tol-Pal system encompassing five proteins required to maintain outer membrane integrity [46] and amyloid-dependent biofilm assembly [47]. Tol-Pal cascade deactivates RcsB/A system and downregulates OmpR expression [47]. $\mathrm{RcsB} / \mathrm{A}$ blocks $\operatorname{csg} B A C$ operon and inhibits CsgA expression whereas, OmpR increases $\operatorname{csg} D$ expression [47].

BolA-like protein family: Proteins belonging to BolA-like protein family are genetic regulators and its homologues are conserved from prokaryotes to eukaryotic organisms [48]. E. coli BolA (encoded by bolA) is a transcriptional switch and a stress regulator protein that governs a variety of phenotypes including biofilm formation, bacterial morphology, membrane permeability, and flagella formation [48,49]. Recently, BolA was found to be involved in curli formation by directly binding to csg operon and positively influencing its expression [49].

Other regulators: A recent study suggests a positive role of purine biosynthesis genes purF, purD, purM, and purK in curli expression [50]. Apart from purine biosynthesis gene, the disrupted putative membrane protein IgaA homolog; YrfF results in curli downregulation [50]. Mutated YrfF gene displays uncontrolled colanic acid production by over-expression of Rcs two-component system that negatively controls transcription of curli genes [50]. Furthermore, in the same study, a novel negative regulator of $\operatorname{csg} D$ and $\operatorname{csg} A$ transcription, named repressor of curli production (RcpA) was identified [50]. As summarized in Figure 2, the post-transcriptional regulation of $\operatorname{csg} D$, several inducers, and repressors collectively modulate csg expression and contribute to amyloid-associated biofilm biogenesis.

\subsection{Bacillus}

B. subtilis is a Gram-positive bacterium widely found in the environment [51]. It forms biofilms on solid surfaces and at the air-liquid interface [51]. The biofilm matrix of B. subtilis is composed of surface hydrophobic layer protein (BslA), major biofilm matrix protein component (TasA), $\gamma$-poly-DL-glutamic acid, and exopolysaccharide comprising galactose, $\mathrm{N}$-acetyl-galactose, and glucose [51]. TasA is an amyloidogenic protein that readily forms amyloids under in vivo and in vitro conditions [17,52]. TasA and exopolysaccharides contribute to the architectural development and structural integrity of the biofilm [52]. TasA anchoring or assembling protein (TapA) assists in fibril assembly of TasA onto cell membrane [53]. The amino-terminal of TasA and TapA are recognized by signal peptidase $\mathrm{W}(\mathrm{SipW})$ that trims the signal peptides during translocation of proteins to the extracellular environment [54]. The expression and secretion of TasA and TapA are under the tight control of tapA-sip $W$-tas $A$ operon [17]. Figure 3 shows the regulation of TasA expression and the accessory proteins required for proper TasA assembly. 


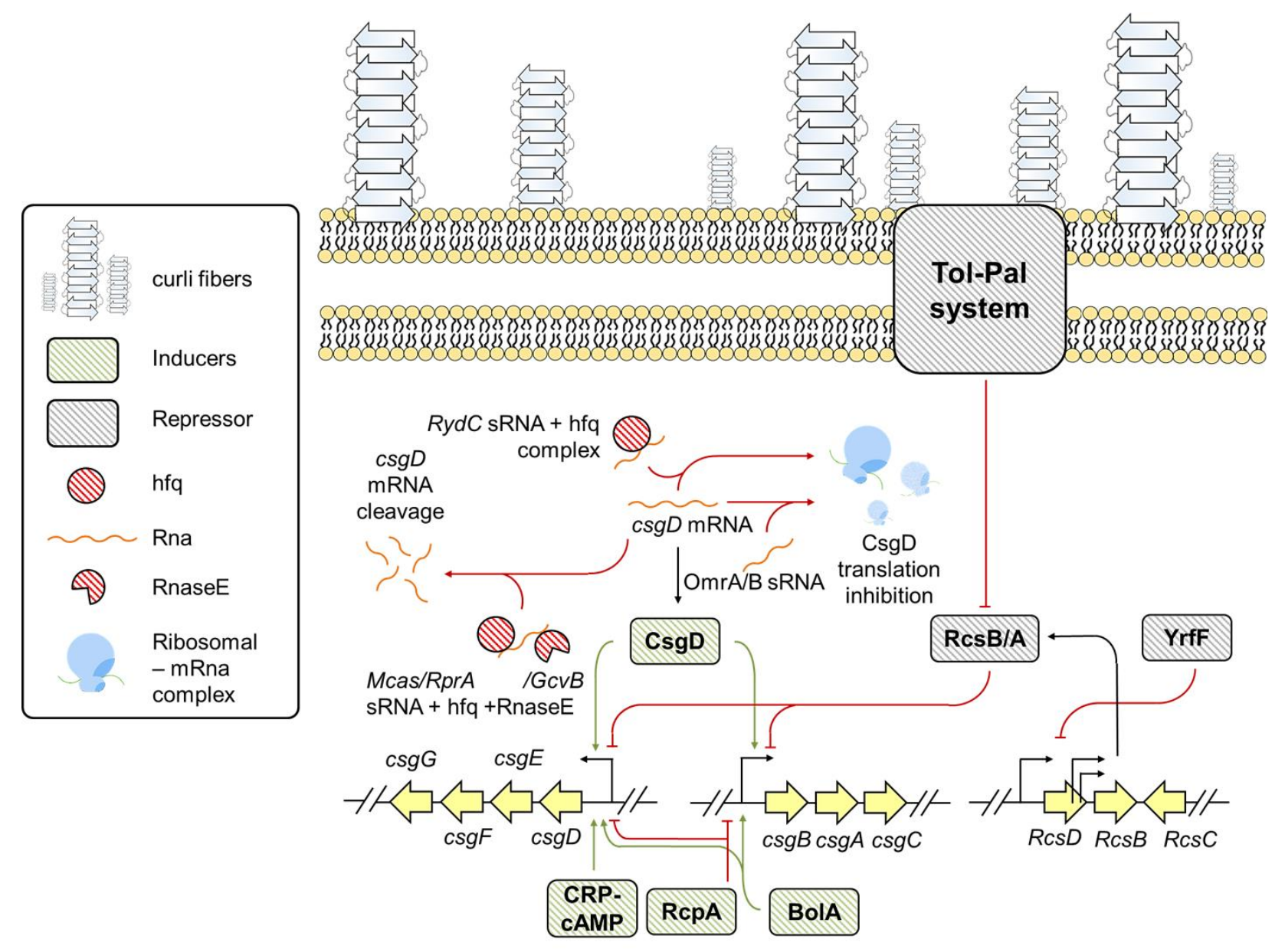

Figure 2. The genetic regulation of $c s g$ transcription in E. coli.

Sporulation transcription factor genes (Spo0A) and HTH-type transcriptional regulator (SlrR): Stage 0 Sporulation Protein A (Spo0A) is a central response regulator protein that regulates the expression of genes involved in matrix synthesis and sporulation [55]. The phosphorylated form of Spo0A (Spo0A P) controls differential gene regulation within the cell [55]. The threshold level of Spo0A P regulates the expression of $\operatorname{tap} A$-sipW-tas $A$ operon by two mechanisms [55]. First, Spo0A P mediates the inhibition of SinR activity [55]. SinR is a master regulator of $B$. subtilis biofilm formation [55]. Under normal conditions, SinR binds to tap $A$ promoter and prevents tap $A$ expression $[55,56]$. However, in response to environmental stimuli, Spo0A P level reaches a threshold that further induces the expression of an anti-repressor protein SinI [55]. SinI forms an irreversible heterodimer with $\operatorname{SinR}$ and thereby prohibits SinR from binding to tap $A$ promoter, leading to tap $A$ expression $[55,57]$. As SinI sequesters $\operatorname{SinR}$, another $\operatorname{Sin} R$ repressed gene, slrR, is transcribed, which further blocks SinR activity [58,59]. Thus, when SinI is expressed under the control of Spo0A P, it inhibits SinR activity, leading to activation and accumulation of SlrR, triggering cells to produce more SlrR [58,59]. The shift from low SlrR to high SlrR state within the bacterial cells is recognized as an epigenetic switch, which helps in biofilm biogenesis for several generations via SinR inhibition by SlrR. Altogether, SinI and SlrR inhibit SinR activity, resulting in tap $A$ expression and contribute to biofilm formation [55]. 


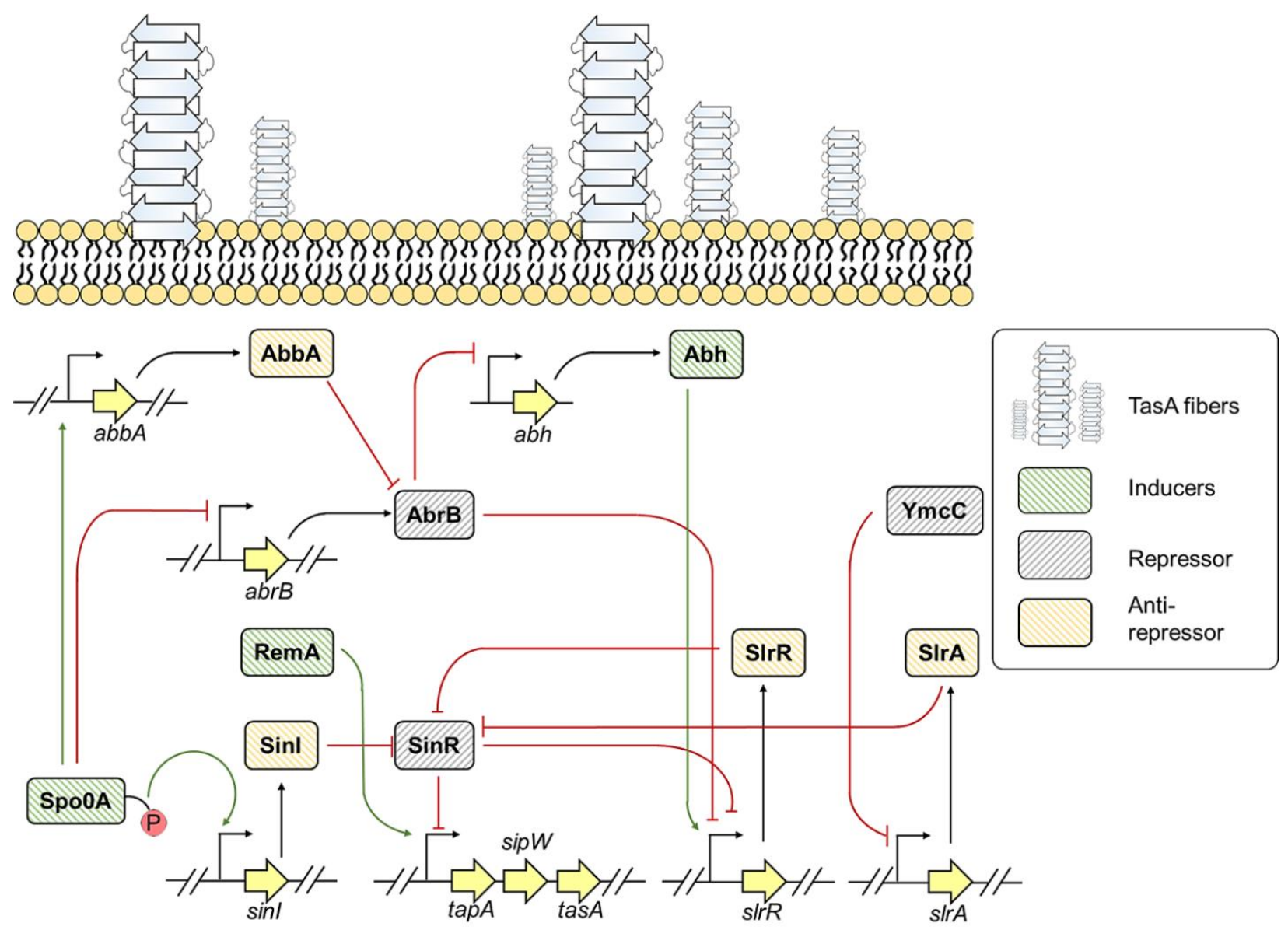

Figure 3. Genetic regulation of TasA expression in B. subtilis.

Secondly, Spo0A P modulates the expression of a regulatory protein AbrB, which is a negative regulator of slrR [55]. This regulation is achieved via two mechanisms: (1) Spo0A P directly represses the expression of $A b r B$, and (2) Spo0A P induces expression of protein $\mathrm{AbbA}$, which sequesters AbrB from slrR promoter [56,58,60,61]. In addition to slrR, AbrB also negatively regulates the abh gene, which positively regulates slrR expression [62]. Some extra-cytoplasmic function (ECF) RNA polymerase $\sigma$-factors transcriptionally regulate abh expression [63]. These factors are activated by various stress signals that suggest a regulatory process independent of Spo0A P response regulatory mechanism [63].

Transcriptional regulator (SlrA): SlrA is a paralog to SinI that is involved in regulating tapA epigenetic switch $[58,64]$. Like SinI, SlrA is also a SinR repressor. Activated SlrA sequesters $\operatorname{SinR}$, leaving the $s l r R$ promoter accessible to the transcription machinery, which leads the cell to a high-SlrR state, resulting in $\operatorname{tap} A$ expression. slr $A$ expression is controlled via transcriptional repressor $\mathrm{YmcC}$. However, what cues relieve $\mathrm{YmcC}$ from the promoter of $\operatorname{sl} A$ are yet to be explored [58,64].

Regulator of extracellular matrix (Rem): RemA and RemB are the two positive proteinregulators essential for manifesting $\operatorname{tap} A$-sip $W$-tas $A$ transcription $[65,66]$. RemA directly binds to the promoter region of $\operatorname{tap} A$ operon and induces the expression. However, the upstream signaling which monitors RemA activity is yet unknown [65,66]. Altogether, inducers, repressors, anti-repressors, and epigenetic switch frames a complex regulatory system that supervises tas $A$ expression and contributes to TasA dependent biofilm formation.

\subsection{Staphylococcus}

Staphylococcus is a Gram-positive bacteria predominantly involved in nosocomial infections [67]. It can adhere to indwelling medical devices and adapt a biofilm lifestyle for better survival [67]. Staphylococcus biofilm matrix consists of eDNA, proteinaceous 
adhesins, aggregates, exopolysaccharides, and teichoic acids [67]. Two proteins, namely phenol soluble modulins (PSMs) and biofilm-a sssociated protein (BAP), greatly influence biofilm development $[18,19,68,69]$. The following section will summarize the genetic control of PSMs and BAP through various regulatory mechanisms.

A. Phenol soluble modulins (PSMs): PSMs are small $\alpha$-helical peptides involved in the virulence of $S$. aureus infections [68,70]. PSMs form amyloid-like structures and assist in biofilm stabilization by protecting the cells against matrix-degrading enzymes [18,71]. However, the monomeric form of PSMs holds relevance in biofilm disassembly [72-74]. There are two variants of PSMs: PSMs $\alpha$ and PSM $\beta$ [70]. The $p s m$ genes are clustered in two loci, expressing the shorter $\alpha$ type 1-4 and the longer $\beta$ type 1 and 2 PSM peptides [70]. S. aureus PSM $\alpha 1, \operatorname{PSM} \alpha 3, \operatorname{PSM} \alpha 4$, and PSM $\beta 1, \operatorname{PSM} \beta 2$ are amyloidogenic $[18,75,76]$. The different forms of PSMs display amyloid polymorphism with PSM $\alpha 1$ and PSM $\alpha 4$ having cross- $\beta$ amyloid fibrils whereas PSM $\alpha 3$ forms cross- $\alpha$ fibrils [77]. S. aureus PSM fibrils involved in biofilm stabilization are majorly composed of PSM $\alpha 1, \operatorname{PSM} \alpha 2, \operatorname{PSM} \alpha 4$, and PSM $\beta 1$, PSM $\beta 2$ peptides [18]. Unlike in vitro PSM amyloid assembly, S. aureus grown in culture media requires eDNA for PSM polymerization [78]. The expression of PSMs is governed by different regulatory factors, as depicted in Figure 4 . Here we report the major regulatory systems responsible for PSM expression:

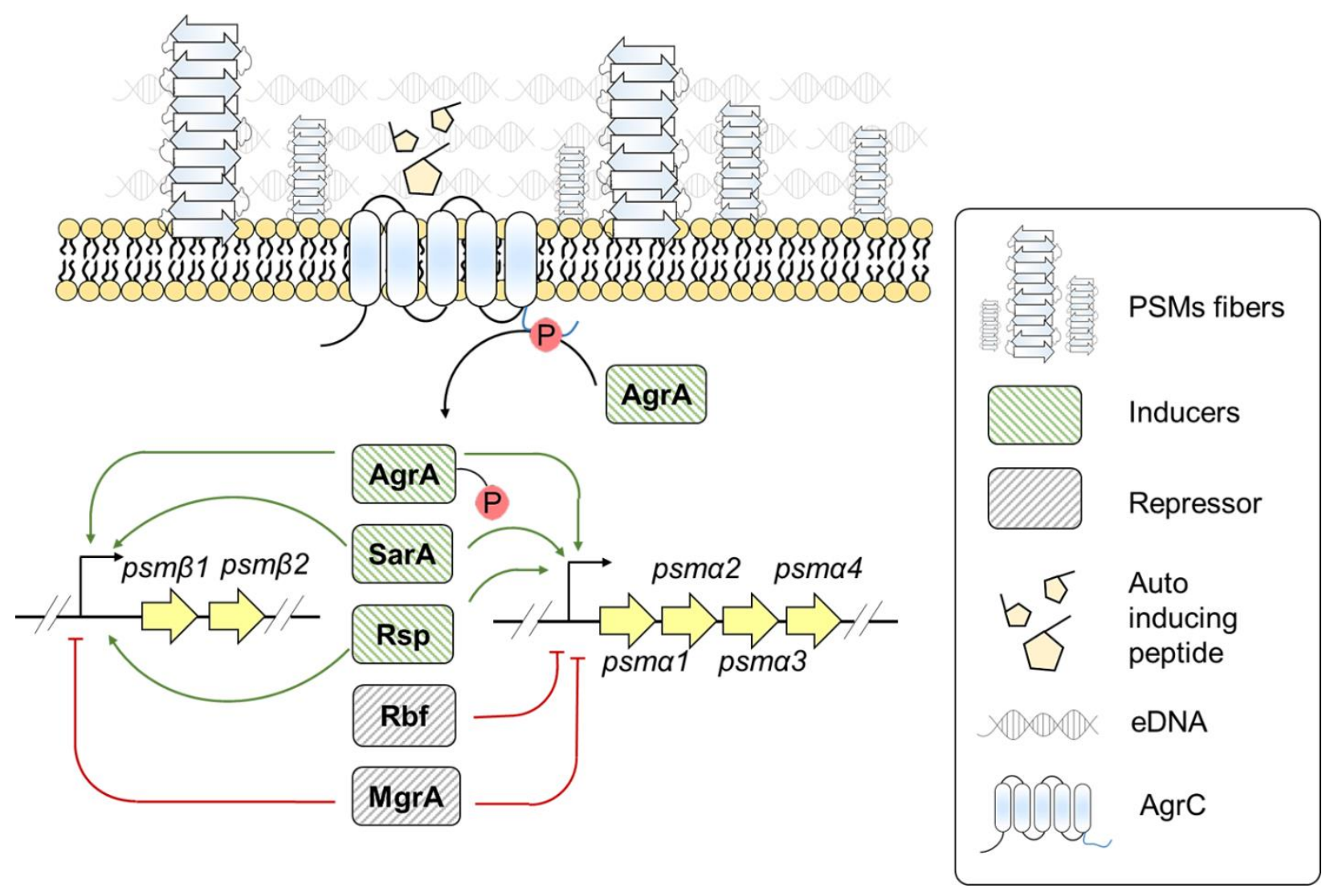

Figure 4. Genetic regulation of psm expression in S. aureus.

Accessory gene regulator (Agr): The Agr system is the main regulatory system that influences the expression of several virulence factors [79]. The Agr system encompasses two divergent transcriptional units, RNAII and RNAIII [79]. RNAII encodes for AgrAD proteins. AgrD is a precursor for an autoinducing peptide [79]. In the presence of autoinducing peptide, the sensor histidine kinase; AgrC activates AgrA that further induces RNAII, RNAIII, and psm gene transcription [79]. The Agr system also appears to be an important regulator for governing psm expression because agr deletion mutants result in downregulation of PSM expression [79]. RNAIII is an Agr effector molecule that 
downregulates the expression of genes involved in the synthesis of surface proteins and upregulates the ones responsible for exoprotein expression [80]. The role of RNAIII in cell death and subsequent increase in eDNA release suggest that the Agr system not only positively regulates PSM expression, but may create an environment that could facilitate PSM polymerization [81].

AraC/XylS-type regulator: The regulator of biofilm formation (Rbf) is an AraC/XylS type regulator modulating Staphylococcus biofilm formation [82]. Rbf directly represses $p s m \alpha$ transcription without significantly affecting $p s m \beta$ transcription [82]. Another AraC family regulatory protein, Rsp, positively influences $p s m \alpha$ and $p s m \beta$ transcription [83]. Rsp influences psm transcription in an Agr-independent manner [83]. Rsp binds to the upstream region of Agr binding site onto $p s m \alpha$ operon, whereas it binds to both upstream and downstream region of Agr binding sites on $p s m \beta$ operon [83]. The PSMs are one of the known agents for causing skin and soft tissue infections [83]. In one of the experiments using mice models, it has been demonstrated that $r s p$ deletion decreases the skin abscesses in mice. However, compared to agr deletion mutants, S. aureus rsp agr double mutant failed to reduce the abscesses area [83]. Rsp seems to regulate PSM expression but may not be a critical regulator as Agr system.

Staphylococcus accessory regulator A (SarA): SarA is another regulator that controls gene expression of virulence factors [84]. A study between foodborne and clinically associated S. aureus strains revealed the positive role of SarA in regulating PSM gene expression [84]. Whether SarA directly or indirectly influences $p s m$ expression is not yet known. Further studies are required to understand the role of SarA in PSM expression.

HTH-type transcriptional regulator (MgrA): MgrA is a transcription regulator that affects PSM expression and biofilm formation [80,85]. It negatively regulates PSM expression by binding to $p s m \alpha$ and $p s m \beta$ operon [85]. However, $m g r A$ deletion mutants display more $p s m \beta$ expression compared to $p s m \alpha$ expression [85], suggesting MgrA has more regulatory effect on $p s m \beta$ compared to $p s m \alpha$ operon. MgrA weakens biofilm detachment at the late biofilm developmental stage by repressing $p s m$ expression; however, its presence discourages biofilm formation at the early developmental state [85].

B. Biofilm-associated protein (Bap): Bap is a cell surface anchored protein that plays a dual role in biofilm formation [86]. The monomeric state of Bap helps in antibiotic resistance, intracellular adhesion whereas the amyloid form elevates clumping and facilitates biofilm assembly on abiotic surfaces and host tissues [86]. After secretion, Bap is covalently attached to the cell surface and processed to release the $\mathrm{N}$-terminus region, which remains soluble at neutral $\mathrm{pH}$, but forms extracellular amyloid-like aggregates when $\mathrm{pH}$ drops to the acidic range [19]. The gene encoding Bap lies within Staphylococcal Pathogenicity Island bovine 2 (SaPIbov2) [87]. SarA is the major regulatory protein that controls Bap expression.

Staphylococcus accessory regulator (SarA): SarA directly promotes Bap-dependent S. aureus biofilm formation [88]. Northern blot analysis reveals reduced bap mRNA in the sarA mutant compared to wild-type [88]. Furthermore, during the late exponential to stationary phase, the expression of $\operatorname{sar} A$ is induced by its $\operatorname{sigB}$ (alternative sigma factor $\mathrm{B}$, a stress response regulator) dependent promoter [89]. Thus, sigB may indirectly impact bap expression via regulating sar $A$ expression at late exponential to stationary phase of bacterial growth [89].

Phase variation: phase variation is a phenomenon that drives the conversion of a non-biofilm-producing phenotype to a biofilm-producing one and vice versa [90]. This phenomenon is also observed in Bap-dependent biofilm-producing S. aureus strains [91]. Under in vitro conditions, S. aureus performs two-way conversion of phase variant phenotype, i.e., from biofilm-positive phenotype to biofilm-negative phenotype and vice versa. However, S. aureus infecting the sheep mammary gland displays one-way phase variant conversion, from biofilm-negative phenotype to biofilm-positive phenotype [91]. The negative biofilm phase variants of $S$. aureus have a reduced Bap expression, whereas the positive phase variants display higher Bap levels [91]. 


\section{Targeting Functional Amyloids Transcriptional Regulation as an Anti-Biofilm Strategy}

The biofilm community display resistance mechanisms against the conventional antibiotic through incomplete or slow permeability of antibiotics to matrix milieu, presence of different cell subpopulation, and altered chemical environment within the biofilm [92]. One way to tackle the biofilm mediated antibiotic resistance is to target the process involved in biofilm formation itself in combination with different antibiotic and/or antimicrobial compounds [93]. Here, we enlist some of the small molecules and/or natural compounds that can target genetic regulation of biofilm-associated functional amyloids (PSMs and curli) in combination with antibiotics or alone as a successful anti-biofilm strategy.

Staphylococcus spp.: A computational approach suggested 4-[(2,4-diflurobenzyl)amino] cyclohexanol as the best small molecule to target Staphylococcus sarA [94] 4-[(2,4-diflurobenzyl) amino] cyclohexanol showed anti-biofilm activity against clinically isolated multidrug resistance $S$. aureus strains, but not the anti-bacterial activity [95]. It also reduced the minimum inhibitory concentration of the antibiotic during combinational studies. Cinnamaldehyde, a major component of cinnamon essential oil present in barks and leaves of cinnamon trees, displays dose dependent anti-biofilm and antibacterial activity [96]. Cinnamaldehyde treated methicillin-resistant Staphylococcus aureus strains had lower levels of sarA mRNA [96]. As SarA positively control bap and psm expression, cinnamaldehyde and 4-[(2,4-diflurobenzyl)amino] cyclohexanol may have impact in downregulating their expression $[84,88,96]$. The dose dependent effect of thymol on MRSA results in MRSA biofilm inhibition [97]. However, once the dose exceeds $100 \mu \mathrm{g} / \mathrm{mL}$, thymol displays antibacterial effects. Thymol mediated significant downregulation of sar $A$ and sarA regulated virulent genes expression [97]. Thus, thymol have the potential to downregulate bap and $\mathrm{psm}$ transcription via interfering sarA expression. Additionally, rifampicin in combination with thymol ameliorates its antibacterial activity onto planktonic and preformed S. aureus biofilm cells. Moreover, 5-Dodecanolide (DD) is a phytochemical exhibiting anti-biofilm activity against MRSA and other clinical associated S. aureus strains. C. elegance treated with DD demonstrated 64\% reduction in MRSA colonization compared to non-treated control [98]. DD promotes agr, RNAIII, PSM $\alpha$, expression and downregulates sar $A$ transcription [98]. DD treated cells showed elevated DNase and protease activity. Interestingly, DD decreases eDNA release in dosage dependent manner [98]. PSM in a lesser or no eDNA environment remains in a monomeric state within the culture medium. The monomeric state of PSM assist in biofilm disassembly $[18,69,72,73,78,99]$. Altogether, the increased expression of PSM in a lesser eDNA environment along with elevated protease activity could be a possible mechanism of DD to exhibit anti-biofilm activity.

Escherichia spp.: Epigallocatechin gallate (EGCG) is a green tea polyphenol that has been shown to inhibit $E$. coli biofilm formation and possess antibacterial activity at a much higher concentration [100]. EGCG inhibits curli expression and amyloid formation via reduced expression of $\operatorname{csg} D$ in E. coli cells [100]. Curli has been known to play an important role in early progression of Parkinson's disease in $\alpha$ - synuclein overexpressing mice [101] by accelerating $\alpha$-synuclein amyloid formation. However, the presence of EGCG not only inhibits curli mediated amyloid formation but also improves motor impairment in $\alpha$-synuclein overexpressing mice [101]. Likewise, EGCG inhibits amyloid formation by human proteins such as transthyretin (TTR), $\alpha$-synuclein and amyloid- $\beta$ peptide [102-105].

Thus, EGCG is a potential candidate for inhibition of amyloid-dependent biofilm formation. Another phenolic compound named ginkgolic acids from G. biloba profoundly inhibits Enterohemorrhagic E. coli O157:H7 (EHEC) biofilm formation [106,107]. Similarly, coumarin and umbelliferone have anti-biofilm effect on E. coli O157:H7 strain [108]. Furthermore, coumarin also modulates motility, quorum sensing and toxin related gene expression. In another study, 83 essential oils for inhibiting Enterohemorrhagic E. coli O157:H7 (EHEC) biofilm were evaluated out of which pimento berry, clove, cinnamon bark, and bay oil gave the best result, reducing more than 75\% of the biofilms [109]. Further analysis suggested the eugenols to be the essential components for its anti-biofilm activity of the oils [109]. In an animal model of $C$. elegans infected with EHEC, it was observed that the worms survived 
when treated with clove or eugenols as compared to non-treated controls [109]. Phloretin, an antioxidant present in apples, demonstrate anti-biofilm activity against E. coli O157:H7. Phloretin repress autoinducer-2, curli and toxic gene expression [110]. In a dose dependent manner, the honey from different floral sources such as clover, acacia and polyfloral display E. coli O157:H7 biofilm inhibition. Along with downregulation of csg gene, honey reduces quorum sensing and virulence gene expression within E. coli O157:H7 [111]. Altogether, different kinds of chemicals have been explored to target the genetic regulators involved in functional amyloid regulation.

\section{Environmental Factor Regulating Gene Expression of Biofilm-associated Amyloids}

The bacterial cells sense and respond to environmental cues via altered gene expression. Modulation in gene expression results in a change of protein pool within the cytoplasmic milieu that governs the formation or dissociation of the biofilm matrix [25]. Therefore, it is of prime interest to study the environmental factors that affect the regulation of matrix components. Here, we discuss some of the environmental factors that regulate the expression of biofilm-associated amyloids.

\section{Environmental Factors Influencing csg Expression in E. coli}

The adequate expression of curli depends on several environmental factors such as altered osmolarity, low temperature, and stationary growth phase conditions, as shown in Figure 5 [112-114]. During low osmolarity conditions, EnvZ/OmpR two-component system and histone like nucleoid structuring (H-NS) protein drive csg expression [115]. EnvZ is a sensory kinase of EnvZ/OmpR two-component system that senses osmolarity change and phosphorylates $\mathrm{OmpR}$, which positively regulates $\operatorname{csg} D$ expression $[114,116]$. However, at low osmolarity and high salt condition or in the presence of high sucrose concentration, H-NS represses csgD expression [114]. CpxA/CpxR two-component system also influences csg expression [114]. CpxA possesses kinase phosphatase activity, whereas CpxR is a response regulator of a two-component system. Under physiological conditions, more phosphatase and less kinase activity of CpxA onto response regulator CpxR is observed, leading to de-repressed activity of the downstream targets [112]. Whereas in high salt concentration, phosphorylated CpxR hampers $\operatorname{csg} D$ expression thereby reducing $\operatorname{csg} A$ transcription $[112,114]$. Besides, at high sucrose or salt concentration, RcsC sensory kinase from Rcs two-component system phosphorylates RcsB contributing to csg downregulation $[114,117,118]$.

Temperature is another major environmental factor that regulates curli expression [113]. Some strains of E. coli synthesize curli at low temperature $\left(\sim 30^{\circ} \mathrm{C}\right)$, which is accomplished by a small protein called Crl [113], levels of which are elevated during the transition to stationary phase [113]. Crl forms holoenzyme with the alternative sigma factor $\sigma^{\mathrm{s}}$ (RpoS) and activates $\operatorname{csg} B A$ promoter [113]. Natural F plasmids in E. coli strains lead to the curli biogenesis by upregulating $\operatorname{csg} B A C$ operon at $37^{\circ} \mathrm{C}$ [119]. Altogether, a thermosensing mechanism allows $\operatorname{csg} A$ expression at various temperatures [113].

The presence of metals also enhances curli expression [120]. Exposure to sub-inhibitory level of nickel leads to high expression of curli and biofilm thickening [120]. Similarly, sulfur is required for E. coli surface adhesion and biofilm formation. Sulfate is the primary source of sulfur as it is abundant in the environment. Once taken up by the bacterium, sulfate is reduced to hydrogen sulfide via an assimilation pathway [121] that results in formation of two nucleotides: adenosine $5^{\prime}$-phosphosulfate (APS) and phosphoadenosine $5^{\prime}$-phosphosulfate (PAPS) [122]. The inactivation of PAPS reductase coding gene $c y s H$ leads to the overproduction of PAPS in the medium, which promotes curli production [121]. Along with metals, antioxidants, such as vitamin $C$ in its minimum inhibitory concentration, inhibits biofilm formation by $E$. coli. Vitamin $C$ affects the quorum sensing activity and exopolysaccharide production, thereby interfering with downregulation of genes responsible for biofilm formation such as $\operatorname{csg} A, \operatorname{csg} G$, and fim $A$ [123]. 


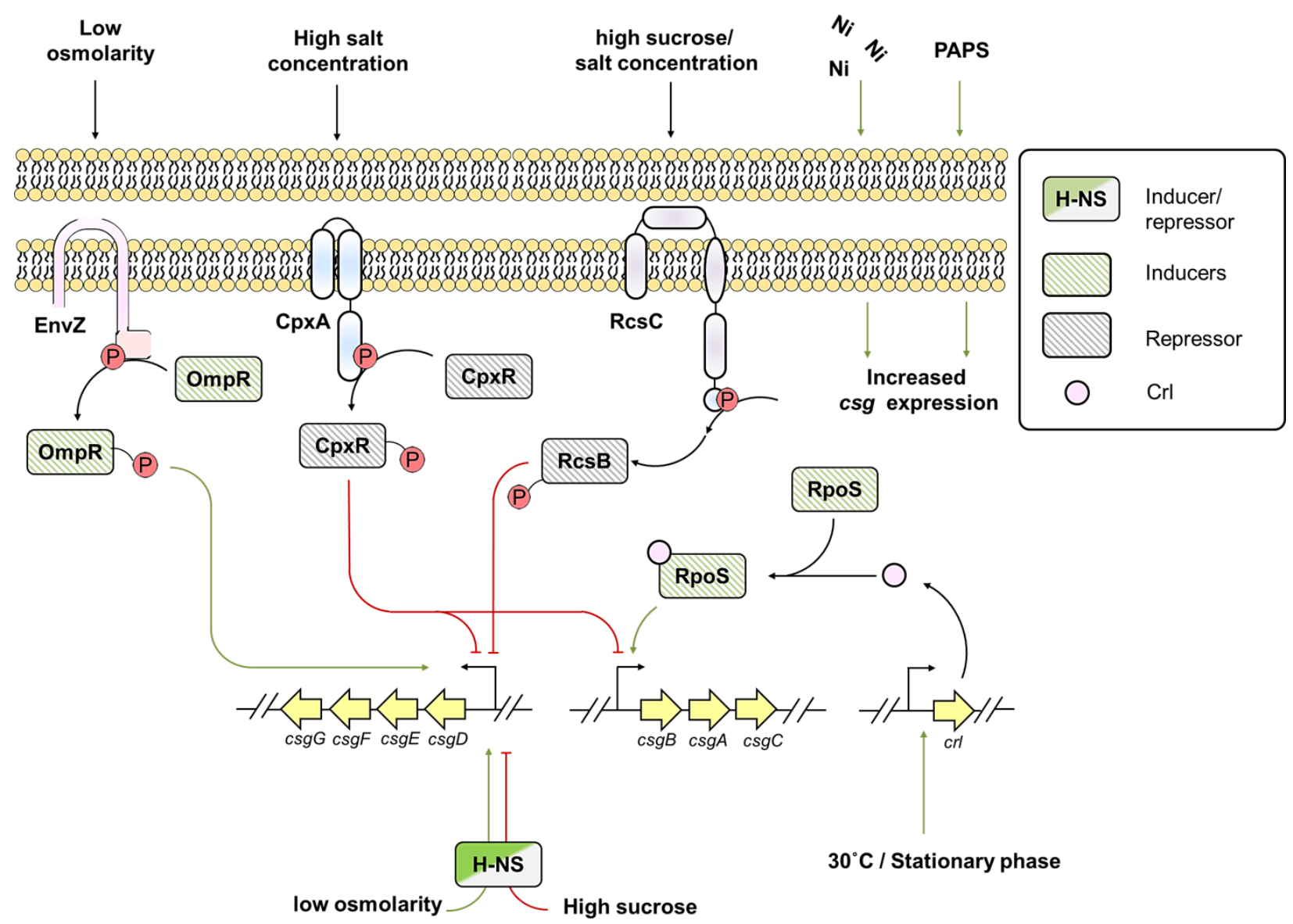

Figure 5. Interplay between various environmental factors that regulates $\operatorname{cs} g$ transcription.

\section{Environmental Factors Regulating TasA Expression in B. subtilis}

B. subtilis fends against various environmental stresses such as osmotic pressure, nutrient availability, and bactericidal agents [124,125]. The osmotic pressure created either by the addition of polyethylene glycol (PEG) or due to the presence of exopolysaccharide results in downregulation of tapA-sipW-tas $A$ operon, thereby inhibiting gene expression of matrix components [124]. The inhibitory effect is $\operatorname{SinR}$ and KinD dependent [124]. KinD is a phosphotransferase, being part of the network that can phosphorylate Spo0A [124]. Threshold levels of Spo0A P facilitated tasA expression [55,57]. Elevated Spo0A P levels are required to stimulate the significant expression of sporulation specific gene SpoAII. Besides, the presence of PEG leads to KinD dependent SpoIIA expression [124]. Interestingly, $B$. subtilis need to bypass the matrix formation to achieve a sporulation state which is also KinD dependent [126]. Altogether, higher osmotic pressure will elevate Spo0A P levels that may bypass the matrix formation, downregulating tas $A$ expression, and aid in sporulation $[124,126]$.

Molecules and metabolites such as nystatin from Streptomyces and auto-inducers like surfactin can stimulate biofilm formation in Bacillus [125]. Surfactin, nystatin, and valinomycin can disrupt cell membrane leading to potassium leakage [125]. The potassium leakage is sensed by Sporulation kinase $\mathrm{C}(\mathrm{KinC})$ that phosphorylates Spo0A resulting in Spo0A P production. When Spo0A P reaches a threshold level, the sub-population produces a biofilm matrix via stimulating tas $A$ operon (Figure 6) [125]. This gives an insight into how Bacillus spp. establishes communication with other microbes and colonize in unfavorable environmental conditions [125]. 


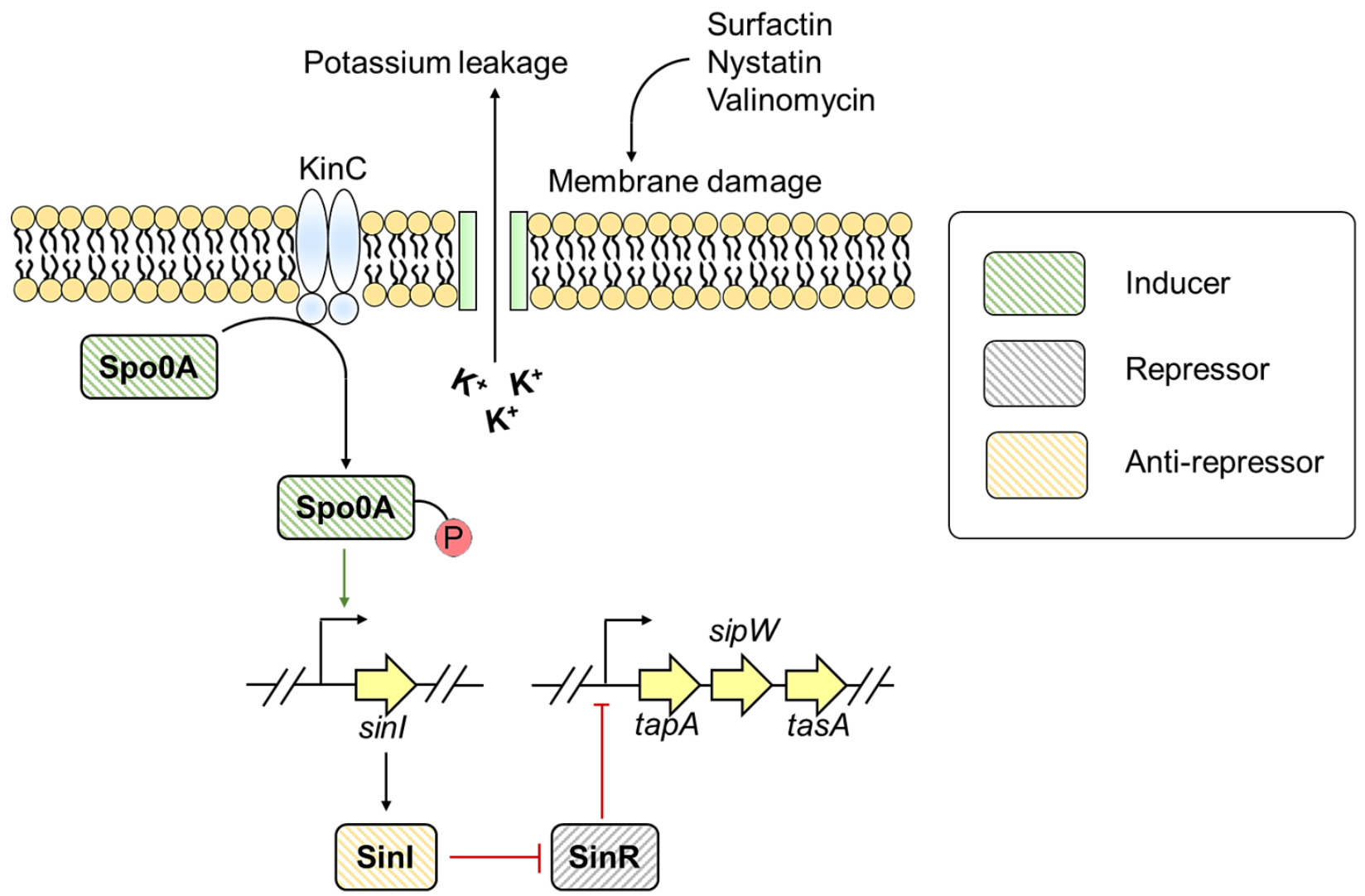

Figure 6. Role of antibiotics and antifungal in modulating Tas $A$ expression.

Under nutritional stress, $B$. subtilis displays cannibalism that delays or avoids entry into the sporulation phase [125]. Certain bacteriocins, such as surfactin, trigger the production of cannibal toxins (sporulation killing factor, sporulation delaying protein) and matrix components like TasA [125] that favors the growth of matrix producers. In contrast, the cells that are unable to transcribe matrix-producing genes are lysed. The lysed cells secrete a set of nutrients on which matrix producers feed, grow, and delay the entry into the sporulation phase [125].

\section{Conclusions}

Biofilm assembly is a highly regulated process with various genes playing a pivotal role in the synthesis and organization of matrix components. Amyloids, being a robust scaffold, contribute significantly to the architecture of the majority of bacterial biofilms. Dedicated systems and genes strictly regulate the amyloid assembly during biofilm formation. Bacterial amyloid acts as a double-edged sword as it provides structural-functional aspects to the biofilm and contributes to the manifestation of numerous infectious diseases. Therefore, understanding the genetic control of amyloids will help us target the genes involved in its regulatory mechanism and pave the way to curb amyloid-associated biofilm infections.

Funding: This research was funded by [Indian Indian Institute of Technology Jodhpur] grant number [I/SEED/NJ/20190019] and [Science and Engineering Research Board] grant number [ECR/2018/002490]. And The APC was waived.

Institutional Review Board Statement: Not applicable.

Informed Consent Statement: Not applicable.

Data Availability Statement: No new data were created or analyzed in this study. Data sharing is not applicable to this article. 
Acknowledgments: We thank the Jain lab members for their critical suggestions on the manuscript. The seed grant from the Indian Institute of Technology Jodhpur (to N.J.), the Early Career Research Award (to N.J.), and project assistantship (to V.S.) by the Science and Engineering Research Board, and the junior research fellowship (to K.K. and J.P.) from the Ministry of Human Resource Development are duly acknowledged.

Conflicts of Interest: The authors declare no conflict of interest.

\section{References}

1. O'Toole, G.; Kaplan, H.B.; Kolter, R. Biofilm formation as microbial development. Annu. Rev. Microbiol. 2000, 54, 49-79. [CrossRef]

2. Nadell, C.D.; Xavier, J.B.; Foster, K.R. The sociobiology of biofilms. FEMS Microbiol. Rev. 2008, 33, 206-224. [CrossRef]

3. Høiby, N. A short history of microbial biofilms and biofilm infections. APMIS 2017, 125, 272-275. [CrossRef]

4. Karygianni, L.; Ren, Z.; Koo, H.; Thurnheer, T. Biofilm matrixome: Extracellular components in structured microbial communities. Trends Microbiol. 2020, 28, 668-681. [CrossRef]

5. Flemming, H.-C.; Baveye, P.; Neu, T.R.; Stoodley, P.; Szewzyk, U.; Wingender, J.; Wuertz, S. Who put the film in biofilm? the migration of a term from wastewater engineering to medicine and beyond. npj Biofilms Microbiomes 2021, 7, 1-5. [CrossRef]

6. Flemming, H.C.; Wingender, J.; Szewzyk, U.; Steinberg, P.; Rice, S.A.; Kjelleberg, S. Biofilms: An emergent form of bacterial life. Nat. Rev. Microbiol. 2016, 14, 563-575. [CrossRef]

7. Fong, J.N.C.; Yildiz, F.H. Biofilm matrix proteins. Microbiol. Spectr. 2015, 3, 201-222. [CrossRef] [PubMed]

8. Van Gerven, N.; Van der Verren, S.E.; Reiter, D.M.; Remaut, H. The role of functional amyloids in bacterial virulence. J. Mol. Biol. 2018, 430, 3657-3684. [CrossRef]

9. Eisenberg, D.; Jucker, M. The amyloid state of proteins in human diseases. Cell 2012, 148, 1188-1203. [CrossRef] [PubMed]

10. Fowler, D.M.; Koulov, A.V.; Balch, W.E.; Kelly, J.W. Functional amyloid-From bacteria to humans. Trends Biochem. Sci. 2007, 32, 217-224. [CrossRef]

11. Deshmukh, M.; Evans, M.L.; Chapman, M.R. Amyloid by design: Intrinsic regulation of microbial amyloid assembly. J. Mol. Biol. 2018, 430, 3631-3641. [CrossRef]

12. Otzen, D.; Riek, R. Functional amyloids. Cold Spring Harb. Perspect. Biol. 2019, 11, a033860. [CrossRef]

13. Balistreri, A.; Goetzler, E.; Chapman, M. Functional amyloids are the rule rather than the exception in cellular biology. Microorganisms 2020, 8, 1951. [CrossRef]

14. Gebbink, M.F.B.G.; Claessen, D.; Bouma, B.; Dijkhuizen, L.; Wösten, H.A.B. Amyloids-a functional coat for microorganisms. Nat Rev. Microbiol. 2005, 3, 333-341. [CrossRef] [PubMed]

15. Chapman, M.R.; Robinson, L.S.; Pinkner, J.S.; Roth, R.; Heuser, J.; Hammar, M.; Normark, S.; Hultgren, S.J. Role of Escherichia coli curli operons in directing amyloid fiber formation. Science 2002, 295, 851-855. [CrossRef] [PubMed]

16. Dueholm, M.S.; Petersen, S.V.; Sønderkær, M.; Larsen, P.; Christiansen, G.; Hein, K.L.; Enghild, J.J.; Nielsen, J.L.; Nielsen, K.L.; Nielsen, P.H.; et al. Functional amyloid in Pseudomonas. Mol. Microbiol. 2010, 77, 1009-1020. [CrossRef]

17. Romero, D.; Aguilar, C.; Losick, R.; Kolter, R. Amyloid fibers provide structural integrity to Bacillus subtilis biofilms. Proc. Natl. Acad. Sci. USA 2010, 107, 2230-2234. [CrossRef] [PubMed]

18. Schwartz, K.; Syed, A.K.; Stephenson, R.E.; Rickard, A.H.; Boles, B.R. Functional amyloids composed of phenol soluble modulins stabilize Staphylococcus aureus biofilms. PLoS Pathog. 2012, 8, e1002744. [CrossRef]

19. Taglialegna, A.; Navarro, S.; Ventura, S.; Garnett, J.A.; Matthews, S.; Penades, J.R.; Lasa, I.; Valle, J. Staphylococcal bap proteins build amyloid scaffold biofilm matrices in response to environmental signals. PLoS Pathog. 2016, 12, e1005711. [CrossRef]

20. Dragoš, A.; Kovács, Á.T.; Claessen, D. The role of functional amyloids in multicellular growth and development of gram-positive bacteria. Biomolecules 2017, 7, 60. [CrossRef]

21. Vidakovic, L.; Singh, P.K.; Hartmann, R.; Nadell, C.D.; Drescher, K. Dynamic biofilm architecture confers individual and collective mechanisms of viral protection. Nat. Microbiol. 2018, 3, 26-31. [CrossRef]

22. Tursi, S.A.; Tükel, Ç. Curli-containing enteric biofilms inside and out: Matrix composition, immune recognition, and disease implications. Microbiol. Mol. Biol. Rev. 2018, 82, e00028-18. [CrossRef] [PubMed]

23. Friedland, R.P.; Chapman, M.R. The role of microbial amyloid in neurodegeneration. PLoS Pathog. 2017, 13, e1006654. [CrossRef] [PubMed]

24. Nicastro, L.; Tükel, Ç. Bacterial amyloids: The link between bacterial infections and autoimmunity. Trends Microbiol. 2019, 27, 954-963. [CrossRef]

25. Wolska, K.I.; Grudniak, A.M.; Rudnicka, Z.; Markowska, K. Genetic control of bacterial biofilms. J. Appl. Genet. 2016, 57, 225-238. [CrossRef]

26. Parsek, M.R.; Greenberg, E.P. Sociomicrobiology: The connections between quorum sensing and biofilms. Trends Microbiol. 2005, 13, 27-33. [CrossRef]

27. Prigent-Combaret, C.; Prensier, G.; Le Thi, T.T.; Vidal, O.; Lejeune, P.; Dorel, C. Developmental Pathway for biofilm formation in curli-producing Escherichia coli strains: Role of flagella, curli and colanic acid. Environ. Microbiol. 2000, 2, 450-464. [CrossRef]

28. Hufnagel, D.A.; Depas, W.H.; Chapman, M.R. The biology of the Escherichia coli extracellular matrix. Microbiol. Spectr. 2015, 3, 249-267. [CrossRef] 
29. Jain, N.; Chapman, M.R. Bacterial functional amyloids: Order from disorder. Biochim. Biophys. Acta Proteins Proteom. 2019, 1867, 954-960. [CrossRef]

30. Bhoite, S.; van Gerven, N.; Chapman, M.R.; Remaut, H. Curli biogenesis: Bacterial amyloid assembly by the Type VIII secretion pathway. Ecosal Plus 2019, 8, 163-171.

31. Hammer, N.D.; Schmidt, J.C.; Chapman, M.R. The curli nucleator protein, CsgB, contains an amyloidogenic domain that directs CsgA polymerization. Proc. Natl. Acad. Sci. USA 2007, 104, 12494-12499. [CrossRef]

32. Hammer, N.D.; McGuffie, B.A.; Zhou, Y.; Badtke, M.P.; Reinke, A.A.; Brännström, K.; Gestwicki, J.E.; Olofsson, A.; Almqvist, F.; Chapman, M.R. The c-terminal repeating units of CsgB direct bacterial functional amyloid nucleation. J. Mol. Biol. 2012, 422, 376-389. [CrossRef]

33. Evans, M.L.; Chorell, E.; Taylor, J.D.; Åden, J.; Götheson, A.; Li, F.; Koch, M.; Sefer, L.; Matthews, S.J.; Wittung-Stafshede, P.; et al . The bacterial curli system possesses a potent and selective inhibitor of amyloid formation. Mol. Cell 2015, 57, 445-455. [CrossRef] [PubMed]

34. Goyal, P.; Krasteva, P.V.; Van Gerven, N.; Gubellini, F.; Van den Broeck, I.; Troupiotis-Tsaillaki, A.; Jonckheere, W.; Péhau-Arnaudet, G.; Pinkner, J.S.; Chapman, M.R.; et al. Structural and mechanistic insights into the bacterial amyloid secretion channel CsgG. Nature 2014, 516, 250-253. [CrossRef]

35. Nenninger, A.A.; Robinson, L.S.; Hammer, N.D.; Epstein, E.A.; Badtke, M.P.; Hultgren, S.J.; Chapman, M.R. CsgE is a curli secretion specificity factor that prevents amyloid fibre aggregation. Mol. Microbiol. 2011, 81, 486-499. [CrossRef]

36. Klein, R.D.; Shu, Q.; Cusumano, Z.T.; Nagamatsu, K.; Gualberto, N.C.; Lynch, A.J.L.; Wu, C.; Wang, W.; Jain, N.; Pinkner, J.S.; et al Structure-function analysis of the curli accessory protein CsgE defines surfaces essential for coordinating amyloid fiber formation. MBio 2018, 9, e01349-18. [CrossRef]

37. Schubeis, T.; Spehr, J.; Viereck, J.; Köpping, L.; Nagaraj, M.; Ahmed, M.; Ritter, C. Structural and functional characterization of the curli adaptor protein CsgF. FEBS Lett. 2018, 592, 1020-1029. [CrossRef]

38. Barnhart, M.M.; Chapman, M.R. Curli biogenesis and function. Annu. Rev. Microbiol. 2006, 60, 131-147. [CrossRef]

39. Smith, J.F.; Knowles, T.P.J.; Dobson, C.M.; Macphee, C.E.; Welland, M.E. Characterization of the nanoscale properties of individual amyloid fibrils. Proc. Natl. Acad. Sci. USA 2006, 103, 15806-15811. [CrossRef]

40. Brombacher, E.; Baratto, A.; Dorel, C.; Landini, P. Gene expression regulation by the curli activator csgd protein: Modulation of cellulose biosynthesis and control of negative determinants for microbial adhesion. J. Bacteriol. 2006, 188, 2027-2037. [CrossRef]

41. Ogasawara, H.; Ishizuka, T.; Hotta, S.; Aoki, M.; Shimada, T.; Ishihama, A. novel regulators of the CsgD gene encoding the master regulator of biofilm formation in Escherichia coli k-12. Microbiology 2020, 166, 880-890. [CrossRef]

42. Hufnagel, D.A.; Evans, M.L.; Greene, S.E.; Pinkner, J.S.; Hultgren, S.J.; Chapman, M.R. The catabolite repressor protein-cyclic amp complex regulates CsgD and biofilm formation in uropathogenic Escherichia coli. J. Bacteriol. 2016, 198, 3329-3334. [CrossRef]

43. Holmqvist, E.; Reimegård, J.; Sterk, M.; Grantcharova, N.; Römling, U.; Wagner, E.G.H. Two antisense RNAs target the transcriptional regulator CsgD to inhibit curli synthesis. EMBO J. 2010, 29, 1840-1850. [CrossRef]

44. Bordeau, V.; Felden, B. Curli synthesis and biofilm formation in enteric bacteria are controlled by a dynamic small RNA module made up of a pseudoknot assisted by an RNA chaperone. Nucleic Acids Res. 2014, 42, 4682-4696. [CrossRef]

45. Andreassen, P.R.; Pettersen, J.S.; Szczerba, M.; Valentin-Hansen, P.; Møller-Jensen, J.; Jørgensen, M.G. SRNA-dependent control of curli biosynthesis in Escherichia coli: McaS directs endonucleolytic cleavage of CsgD MRNA. Nucleic Acids Res. 2018, 46, 6746-6760. [CrossRef]

46. Gerding, M.A.; Ogata, Y.; Pecora, N.D.; Niki, H.; de Boer, P.A.J. The trans-envelope Tol-Pal complex is part of the cell division machinery and required for proper outer-membrane invagination during cell constriction in E. coli. Mol. Microbiol. 2007, 63, 1008-1025. [CrossRef]

47. Vianney, A.; Jubelin, G.; Renault, S.; Dorel, C.; Lejeune, P.; Lazzaroni, J.C. Escherichia coli Tol and Rcs genes participate in the complex network affecting curli synthesis. Microbiology 2005, 151, 2487-2497. [CrossRef]

48. Dressaire, C.; Moreira, R.N.; Barahona, S.; Alves de Matos, A.P.; Arraiano, C.M. BolA is a transcriptional switch that turns off motility and turns on biofilm development. MBio 2015, 6, e02352-14. [CrossRef] [PubMed]

49. Azam, M.W.; Zuberi, A.; Khan, A.U. BolA gene involved in curli amyloids and fimbriae production in E. coli: Exploring pathways to inhibit biofilm and amyloid formation. J. Biol. Res. 2020, 27, 1-12. [CrossRef]

50. Nhu, N.T.K.; Phan, M.-D.; Peters, K.M.; Lo, A.W.; Forde, B.M.; Min Chong, T.; Yin, W.-F.; Chan, K.-G.; Chromek, M.; Brauner, A.; et al. Discovery of new genes involved in curli production by a uropathogenic Escherichia coli strain from the highly virulent O45:K1:H7 lineage. MBio 2018, 9, e01462-18. [CrossRef] [PubMed]

51. Cairns, L.S.; Hobley, L.; Stanley-Wall, N.R. Biofilm formation by Bacillus subtilis: New insights into regulatory strategies and assembly mechanisms. Mol. Microbiol. 2014, 93, 587-598. [CrossRef]

52. Branda, S.S.; Chu, F.; Kearns, D.B.; Losick, R.; Kolter, R. A major protein component of the Bacillus subtilis biofilm matrix. Mol. Microbiol. 2006, 59, 1229-1238. [CrossRef]

53. Romero, D.; Vlamakis, H.; Losick, R.; Kolter, R. An accessory protein required for anchoring and assembly of amyloid fibres in $B$. subtilis biofilms. Mol. Microbiol. 2011, 80, 1155-1168. [CrossRef]

54. Terra, R.; Stanley-Wall, N.R.; Cao, G.; Lazazzera, B.A. Identification of Bacillus subtilis SipW as a bifunctional signal peptidase that controls surface-adhered biofilm formation. J. Bacteriol. 2012, 194, 2781-2790. [CrossRef] 
55. Vlamakis, H.; Chai, Y.; Beauregard, P.; Losick, R.; Kolter, R. Sticking together: Building a biofilm the Bacillus subtilis way. Nat. Rev. Microbiol. 2013, 11, 157-168. [CrossRef] [PubMed]

56. Chu, F.; Kearns, D.B.; McLoon, A.; Chai, Y.; Kolter, R.; Losick, R. A novel regulatory protein governing biofilm formation in Bacillus subtilis. Mol. Microbiol. 2008, 68, 1117-1127. [CrossRef] [PubMed]

57. Newman, J.A.; Rodrigues, C.; Lewis, R.J. Molecular basis of the activity of SinR Protein, the master regulator of biofilm formation in Bacillus subtilis. J. Biol. Chem. 2013, 288, 10766-10778. [CrossRef] [PubMed]

58. Kobayashi, K. SlrR/SlrA controls the initiation of biofilm formation in Bacillus subtilis. Mol. Microbiol. 2008, 69, 1399-1410. [CrossRef] [PubMed]

59. Chai, Y.; Norman, T.; Kolter, R.; Losick, R. An epigenetic switch governing daughter cell separation in Bacillus subtilis. Genes Dev. 2010, 24, 754-765. [CrossRef] [PubMed]

60. Chumsakul, O.; Takahashi, H.; Oshima, T.; Hishimoto, T.; Kanaya, S.; Ogasawara, N.; Ishikawa, S. Genome-wide binding profiles of the Bacillus subtilis transition state regulator AbrB and its homolog abh reveals their interactive role in transcriptional regulation. Nucleic Acids Res. 2011, 39, 414-428. [CrossRef]

61. Tucker, A.T.; Bobay, B.G.; Banse, A.V.; Olson, A.L.; Soderblom, E.J.; Moseley, M.A.; Thompson, R.J.; Varney, K.M.; Losick, R.; Cavanagh, J. A DNA mimic: The structure and mechanism of action for the anti-repressor protein AbbA. J. Mol. Biol. 2014, 426, 1911-1924. [CrossRef] [PubMed]

62. Strauch, M.; Webb, V.; Spiegelman, G.; Hoch, J.A. The SpoOA protein of Bacillus subtilis is a repressor of the AbrB gene. Proc. Natl. Acad. Sci. USA 1990, 87, 1801-1805. [CrossRef]

63. Murray, E.J.; Strauch, M.A.; Stanley-Wall, N.R. SigmaX is involved in controlling Bacillus subtilis biofilm architecture through the AbrB homologue Abh. J. Bacteriol. 2009, 191, 6822-6832. [CrossRef] [PubMed]

64. Chai, Y.; Kolter, R.; Losick, R. Paralogous antirepressors acting on the master regulator for biofilm formation in Bacillus subtilis. Mol. Microbiol. 2009, 74, 876-887. [CrossRef] [PubMed]

65. Winkelman, J.T.; Blair, K.M.; Kearns, D.B. RemA (YlzA) and RemB (YaaB) regulate extracellular matrix operon expression and biofilm formation in Bacillus subtilis. J. Bacteriol. 2009, 191, 3981-3991. [CrossRef]

66. Winkelman, J.T.; Bree, A.C.; Bate, A.R.; Eichenberger, P.; Gourse, R.L.; Kearns, D.B. RemA is a DNA-binding protein that activates biofilm matrix gene expression in Bacillus subtilis. Mol. Microbiol. 2013, 88, 984-997. [CrossRef] [PubMed]

67. Paharik, A.E.; Horswill, A.R. The Staphylococcal biofilm: Adhesins, regulation, and host response. In Virulence Mechanisms of Bacterial Pathogens; John Wiley \& Sons, Ltd: Hoboken, NJ, USA, 2016; pp. 529-566. ISBN 9781683670711.

68. Peschel, A.; Otto, M. Phenol-soluble modulins and Staphylococcal infection. Nat. Rev. Microbiol. 2013, 11, 667-673. [CrossRef]

69. Le, K.Y.; Villaruz, A.E.; Zheng, Y.; He, L.; Fisher, E.L.; Nguyen, T.H.; Ho, T.V.; Yeh, A.J.; Joo, H.-S.; Cheung, G.Y.C.; et al. Role of phenol-soluble modulins in Staphylococcus epidermidis biofilm formation and infection of indwelling medical devices. J. Mol. Biol. 2019, 431, 3015-3027. [CrossRef]

70. Wang, R.; Braughton, K.R.; Kretschmer, D.; Bach, T.-H.L.; Queck, S.Y.; Li, M.; Kennedy, A.D.; Dorward, D.W.; Klebanoff, S.J.; Peschel, A.; et al. Identification of novel cytolytic peptides as key virulence determinants for community-associated MRSA. Nat. Med. 2007, 13, 1510-1514. [CrossRef] [PubMed]

71. Dastgheyb, S.S.; Villaruz, A.E.; Le, K.Y.; Tan, V.Y.; Duong, A.C.; Chatterjee, S.S.; Cheung, G.Y.C.; Joo, H.-S.; Hickok, N.J.; Otto, M. Role of phenol-soluble modulins in formation of Staphylococcus aureus biofilms in synovial fluid. Infect. Immun. 2015, 83, 2966-2975. [CrossRef] [PubMed]

72. Wang, R.; Khan, B.A.; Cheung, G.Y.C.; Bach, T.-H.L.; Jameson-Lee, M.; Kong, K.-F.; Queck, S.Y.; Otto, M. Staphylococcus epidermidis surfactant peptides promote biofilm maturation and dissemination of biofilm-associated infection in mice. J. Clin. Invest. 2011, 121, 238-248. [CrossRef]

73. Cheung, G.Y.C.; Kretschmer, D.; Queck, S.Y.; Joo, H.-S.; Wang, R.; Duong, A.C.; Nguyen, T.H.; Bach, T.-H.L.; Porter, A.R.; DeLeo, F.R.; et al. Insight into structure-function relationship in phenol-soluble modulins using an alanine screen of the phenol-soluble modulin (PSM) A3 peptide. FASEB J. Off. Publ. Fed. Am. Soc. Exp. Biol. 2014, 28, 153-161. [CrossRef]

74. Kizaki, H.; Omae, Y.; Tabuchi, F.; Saito, Y.; Sekimizu, K.; Kaito, C. Cell-surface phenol soluble modulins regulate Staphylococcus aureus colony spreading. PLoS ONE 2016, 11, e0164523. [CrossRef]

75. Marinelli, P.; Pallares, I.; Navarro, S.; Ventura, S. Dissecting the contribution of Staphylococcus aureus $\alpha$-phenol-soluble modulins to biofilm amyloid structure. Sci. Rep. 2016, 6, 1-13. [CrossRef]

76. Tayeb-Fligelman, E.; Tabachnikov, O.; Moshe, A.; Goldshmidt-Tran, O.; Sawaya, M.R.; Coquelle, N.; Colletier, J.-P.; Landau, M. The cytotoxic Staphylococcus aureus PSM $\alpha 3$ reveals a cross- $\alpha$ amyloid-like fibril. Science 2017, 355, 831-833. [CrossRef]

77. Salinas, N.; Colletier, J.-P.; Moshe, A.; Landau, M. Extreme amyloid polymorphism in Staphylococcus aureus virulent PSM $\alpha$ peptides. Nat. Commun. 2018, 9, 1-9. [CrossRef]

78. Schwartz, K.; Ganesan, M.; Payne, D.E.; Solomon, M.J.; Boles, B.R. Extracellular DNA facilitates the formation of functional amyloids in Staphylococcus aureus biofilms. Mol. Microbiol. 2016, 99, 123-134. [CrossRef]

79. Queck, S.Y.; Jameson-Lee, M.; Villaruz, A.E.; Bach, T.-H.L.; Khan, B.A.; Sturdevant, D.E.; Ricklefs, S.M.; Li, M.; Otto, M. RNAIII-independent target gene control by the agr quorum-sensing system: Insight into the evolution of virulence regulation in Staphylococcus aureus. Mol. Cell 2008, 32, 150-158. [CrossRef]

80. Trotonda, M.P.; Tamber, S.; Memmi, G.; Cheung, A.L. MgrA represses biofilm formation in Staphylococcus aureus. Infect. Immun. 2008, 76, 5645-5654. [CrossRef] 
81. Paulander, W.; Varming, A.N.; Bojer, M.S.; Friberg, C.; Bæk, K.; Ingmer, H. The Agr quorum sensing system in Staphylococcus aureus cells mediates death of sub-population. BMC Res. Notes 2018, 11,1-5. [CrossRef]

82. Fang, B.; Liu, B.; Sun, B. Transcriptional regulation of virulence factors Hla and phenol-soluble modulins $\alpha$ by AraC-type regulator Rbf in Staphylococcus aureus. Int. J. Med. Microbiol. 2020, 310, 151436. [CrossRef] [PubMed]

83. Liu, B.; Sun, B. Rsp promotes the transcription of virulence factors in an agr-independent manner in Staphylococcus aureus. Emerg. Microbes Infect. 2020, 9, 796-812. [CrossRef] [PubMed]

84. Wu, X.; Yang, M.; Fang, X.; Zhen, S.; Zhang, J.; Yang, X.; Qiao, L.; Yang, Y.; Zhang, C. Expression and regulation of phenol-soluble modulins and enterotoxins in foodborne Staphylococcus aureus. AMB Express 2018, 8, 1-7. [CrossRef]

85. Jiang, Q.; Jin, Z.; Sun, B. MgrA negatively regulates biofilm formation and detachment by repressing the expression of Psm operons in Staphylococcus aureus. Appl. Environ. Microbiol. 2018, 84, e01008-18. [CrossRef]

86. Cucarella, C.; Solano, C.; Valle, J.; Amorena, B.; Lasa, I.; Penadés, J.R. Bap, a Staphylococcus aureus surface protein involved in biofilm formation. J. Bacteriol. 2001, 183, 2888-2896. [CrossRef]

87. Ubeda, C.; Tormo, M.A.; Cucarella, C.; Trotonda, P.; Foster, T.J.; Lasa, I.; Penadés, J.R. Sip, an integrase protein with excision, circularization and integration activities, defines a new family of mobile Staphylococcus aureus pathogenicity islands. Mol. Microbiol. 2003, 49, 193-210. [CrossRef]

88. Trotonda, M.P.; Manna, A.C.; Cheung, A.L.; Lasa, I.; Penadés, J.R. SarA positively controls bap-dependent biofilm formation in Staphylococcus Aureus. J. Bacteriol. 2005, 187, 5790-5798. [CrossRef]

89. Ziebandt, A.-K.; Becher, D.; Ohlsen, K.; Hacker, J.; Hecker, M.; Engelmann, S. The Influence of Agr and SigmaB in growth phase dependent regulation of virulence factors in Staphylococcus aureus. Proteomics 2004, 4, 3034-3047. [CrossRef]

90. Ziebuhr, W.; Krimmer, V.; Rachid, S.; Lössner, I.; Götz, F.; Hacker, J. A novel mechanism of phase variation of virulence in Staphylococcus epidermidis: Evidence for control of the polysaccharide intercellular adhesin synthesis by alternating insertion and excision of the insertion sequence element IS256. Mol. Microbiol. 1999, 32, 345-356. [CrossRef]

91. Tormo, M.Á.; Úbeda, C.; Martí, M.; Maiques, E.; Cucarella, C.; Valle, J.; Foster, T.J.; Lasa, Í.; Penadés, J.R. Phase-variable expression of the biofilm-associated protein (Bap) in Staphylococcus aureus. Microbiology 2007, 153, 1702-1710. [CrossRef] [PubMed]

92. Sharma, D.; Misba, L.; Khan, A.U. Antibiotics versus biofilm: An emerging battleground in microbial communities. Antimicrob. Resist. Infect. Control 2019, 8, 1-10. [CrossRef]

93. Bowler, P.G. Antibiotic resistance and biofilm tolerance: A combined threat in the treatment of chronic infections. J. Wound Care 2018, 27, 273-277. [CrossRef] [PubMed]

94. Arya, R.; Ravikumar, R.; Santhosh, R.S.; Princy, S. SarA based novel therapeutic candidate against Staphylococcus aureus associated with vascular graft infections. Front. Microbiol. 2015, 6, 416. [CrossRef] [PubMed]

95. Balamurugan, P.; Praveen Krishna, V.; Bharath, D.; Lavanya, R.; Vairaprakash, P.; Adline Princy, S. Staphylococcus aureus quorum regulator SarA targeted compound, 2-[(Methylamino) Methyl] phenol inhibits biofilm and down-regulates virulence genes. Front. Microbiol. 2017, 8, 1290. [CrossRef] [PubMed]

96. Jia, P.; Xue, Y.J.; Duan, X.J.; Shao, S.H. Effect of cinnamaldehyde on biofilm formation and sarA expression by methicillin-resistant Staphylococcus aureus. Lett. Appl. Microbiol. 2011, 53, 409-416. [CrossRef] [PubMed]

97. Valliammai, A.; Selvaraj, A.; Yuvashree, U.; Aravindraja, C.; Karutha Pandian, S. SarA-dependent antibiofilm activity of thymol enhances the antibacterial efficacy of rifampicin against Staphylococcus aureus. Front. Microbiol. 2020, 11, 1744. [CrossRef] [PubMed]

98. Valliammai, A.; Sethupathy, S.; Priya, A.; Selvaraj, A.; Bhaskar, J.P.; Krishnan, V.; Pandian, S.K. 5-Dodecanolide interferes with biofilm formation and reduces the virulence of Methicillin-resistant Saphylococcus aureus (MRSA) through up regulation of Agr system. Sci. Rep. 2019, 9, 1-16. [CrossRef] [PubMed]

99. Periasamy, S.; Joo, H.-S.; Duong, A.C.; Bach, T.-H.L.; Tan, V.Y.; Chatterjee, S.S.; Cheung, G.Y.C.; Otto, M. How Staphylococcus aureus biofilms develop their characteristic structure. Proc. Natl. Acad. Sci. USA 2012, 109, 1281-1286. [CrossRef]

100. Serra, D.O.; Mika, F.; Richter, A.M.; Hengge, R. The green tea polyphenol EGCG inhibits E. coli biofilm formation by impairing amyloid curli fibre assembly and downregulating the biofilm regulator CsgD via the $\Sigma$ E-dependent sRNA RybB. Mol. Microbiol. 2016, 101, 136-151. [CrossRef]

101. Sampson, T.R.; Challis, C.; Jain, N.; Moiseyenko, A.; Ladinsky, M.S.; Shastri, G.G.; Thron, T.; Needham, B.D.; Horvath, I.; Debelius, J.W.; et al. A gut bacterial amyloid promotes a-synuclein aggregation and motor impairment in mice. Elife 2020, 9 , e53111. [CrossRef]

102. Ehrnhoefer, D.E.; Bieschke, J.; Boeddrich, A.; Herbst, M.; Masino, L.; Lurz, R.; Engemann, S.; Pastore, A.; Wanker, E.E. EGCG redirects amyloidogenic polypeptides into unstructured, off-pathway oligomers. Nat. Struct. Mol. Biol. 2008, 15, 558. [CrossRef]

103. Ferreira, N.; Cardoso, I.; Domingues, M.R.; Vitorino, R.; Bastos, M.; Bai, G.; Saraiva, M.J.; Almeida, M.R. Binding of epigallocatechin-3-gallate to transthyretin modulates its amyloidogenicity. FEBS Lett. 2009, 583, 3569-3576. [CrossRef] [PubMed]

104. Lorenzen, N.; Nielsen, S.B.; Yoshimura, Y.; Vad, B.S.; Andersen, C.B.; Betzer, C.; Kaspersen, J.D.; Christiansen, G.; Pedersen, J.S.; Jensen, P.H. How epigallocatechin gallate can inhibit $\alpha$-synuclein oligomer toxicity in vitro. J. Biol. Chem. 2014, 289, 21299-21310. [CrossRef] [PubMed]

105. Ferreira, N.; Pereira-Henriques, A.; Almeida, M.R. Transthyretin chemical chaperoning by flavonoids: Structure-activity insights towards the design of potent amyloidosis inhibitors. Biochem. Biophys. Rep. 2015, 3, 123-133. [CrossRef] [PubMed] 
106. Ndjoko, K.; Wolfender, J.-L.; Hostettmann, K. Determination of trace amounts of ginkgolic acids in Ginkgo biloba L. leaf extracts and phytopharmaceuticals by liquid chromatography-electrospray mass spectrometry. J. Chromatogr. B Biomed. Sci. Appl. 2000, 744, 249-255. [CrossRef]

107. Lee, J.-H.; Kim, Y.-G.; Ryu, S.Y.; Cho, M.H.; Lee, J. Ginkgolic acids and Ginkgo biloba extract inhibit Escherichia coli O157: H7 and Staphylococcus aureus biofilm formation. Int. J. Food Microbiol. 2014, 174, 47-55. [CrossRef]

108. Lee, J.-H.; Kim, Y.-G.; Cho, H.S.; Ryu, S.Y.; Cho, M.H.; Lee, J. Coumarins reduce biofilm formation and the virulence of Escherichia coli O157: H7. Phytomedicine 2014, 21, 1037-1042. [CrossRef] [PubMed]

109. Kim, Y.-G.; Lee, J.-H.; Gwon, G.; Kim, S.-I.; Park, J.G.; Lee, J. Essential oils and eugenols inhibit biofilm formation and the virulence of Escherichia coli O157: H7. Sci. Rep. 2016, 6, 1-11. [CrossRef]

110. Lee, J.-H.; Regmi, S.C.; Kim, J.-A.; Cho, M.H.; Yun, H.; Lee, C.-S.; Lee, J. Apple flavonoid phloretin inhibits Escherichia coli O157:H7 biofilm formation and ameliorates colon inflammation in rats. Infect. Immun. 2011, 79, 4819-4827. [CrossRef]

111. Lee, J.-H.; Park, J.-H.; Kim, J.-A.; Neupane, G.P.; Cho, M.H.; Lee, C.-S.; Lee, J. Low concentrations of honey reduce biofilm formation, quorum sensing, and virulence in Escherichia coli O157: H7. Biofouling 2011, 27, 1095-1104. [CrossRef]

112. Dorel, C.; Vidal, O.; Prigent-Combaret, C.; Vallet, I.; Lejeune, P. Involvement of the Cpx signal transduction pathway of E. coli in biofilm formation. FEMS Microbiol. Lett. 1999, 178, 169-175. [CrossRef] [PubMed]

113. Bougdour, A.; Lelong, C.; Geiselmann, J. Crl, A low temperature-induced protein in Escherichia coli that binds directly to the stationary phase sigma subunit of RNA polymerase. J. Biol. Chem. 2004, 279, 19540-19550. [CrossRef] [PubMed]

114. Jubelin, G.; Vianney, A.; Beloin, C.; Ghigo, J.-M.; Lazzaroni, J.-C.; Lejeune, P.; Dorel, C. CpxR/OmpR interplay regulates curli gene expression in response to osmolarity in Escherichia coli. J. Bacteriol. 2005, 187, 2038-2049. [CrossRef] [PubMed]

115. Prigent-Combaret, C.; Brombacher, E.; Vidal, O.; Ambert, A.; Lejeune, P.; Landini, P.; Dorel, C. Complex regulatory network controls initial adhesion and biofilm formation in Escherichia coli via regulation of the CsgD gene. J. Bacteriol. 2001, 183, 7213-7223. [CrossRef]

116. Ogasawara, H.; Yamada, K.; Kori, A.; Yamamoto, K.; Ishihama, A. Regulation of the Escherichia coli CsgD promoter: Interplay between five transcription factors. Microbiology 2010, 156, 2470-2483. [CrossRef]

117. Sharma, V.K.; Bayles, D.O.; Alt, D.P.; Looft, T.; Brunelle, B.W.; Stasko, J.A. Disruption of RcsB by a duplicated sequence in a curli-producing Escherichia coli O157:H7 results in differential gene expression in relation to biofilm formation, stress responses and metabolism. BMC Microbiol. 2017, 17, 1-13. [CrossRef]

118. Carter, M.Q.; Parker, C.T.; Louie, J.W.; Huynh, S.; Fagerquist, C.K.; Mandrell, R.E. RcsB contributes to the distinct stress fitness among Escherichia coli O157:H7 curli variants of the 1993 hamburger-associated outbreak strains. Appl. Environ. Microbiol. 2012, 78, 7706-7719. [CrossRef]

119. May, T.; Okabe, S. Escherichia coli harboring a natural IncF conjugative F plasmid develops complex mature biofilms by stimulating synthesis of colanic acid and curli. J. Bacteriol. 2008, 190, 7479-7490. [CrossRef]

120. Perrin, C.; Briandet, R.; Jubelin, G.; Lejeune, P.; Mandrand-Berthelot, M.-A.; Rodrigue, A.; Dorel, C. Nickel promotes biofilm formation by Escherichia coli K-12 strains that produce curli. Appl. Environ. Microbiol. 2009, 75, 1723-1733. [CrossRef]

121. Rossi, E.; Motta, S.; Mauri, P.; Landini, P. Sulfate assimilation pathway intermediate phosphoadenosine 59-phosphosulfate acts as a signal molecule affecting production of curli fibres in Escherichia coli. Microbiology 2014, 160, 1832-1844. [CrossRef]

122. Liu, C.; Martin, E.; Leyh, T.S. GTPase activation of ATP sulfurylase: The Mechanism. Biochemistry 1994, 33, 2042-2047. [CrossRef]

123. Shivaprasad, D.P.; Taneja, N.K.; Lakra, A.; Sachdev, D. In vitro and in situ abrogation of biofilm formation in E. coli by vitamin $\mathrm{C}$ through ROS generation, disruption of quorum sensing and exopolysaccharide production. Food Chem. 2021, $341,128171$. [CrossRef] [PubMed]

124. Rubinstein, S.M.; Kolodkin-Gal, I.; McLoon, A.; Chai, L.; Kolter, R.; Losick, R.; Weitz, D.A. Osmotic pressure can regulate matrix gene expression in Bacillus subtilis. Mol. Microbiol. 2012, 86, 426-436. [CrossRef] [PubMed]

125. López, D.; Vlamakis, H.; Losick, R.; Kolter, R. Cannibalism enhances biofilm development in Bacillus subtilis. Mol. Microbiol. 2009, 74, 609-618. [CrossRef]

126. Aguilar, C.; Vlamakis, H.; Guzman, A.; Losick, R.; Kolter, R. KinD is a checkpoint protein linking spore formation to extracellularmatrix production in Bacillus subtilis biofilms. MBio 2010, 1, e0035-10. [CrossRef] [PubMed] 